Volume 03 Nomor 01, Juni 2021 Page 45-50

Incrementapedia: Jurnal Pendidikan Anak Usia Dini

Program Studi PG-PAUD Fakultas Pedagogi dan Psikologi

Universitas PGRI Adi Buana Surabaya

http://jurnal.unipasby.ac.id/index.php/incrementapedia

e-ISSN: 2686-3146

\title{
PERSEPSI ORANG TUA TERHADAP PENDAMPINGAN PEMBELAJARAN DARING DI MASA PANDEMI COVID-19 DI TK
} AL ITTIHAD

\author{
Adolf Bastian ${ }^{\text {a, }}$ Suharni ${ }^{\mathrm{b}}$ Heleni filtri ${ }^{\mathrm{c}}$ \\ ${ }^{a}$ Universitas Lancang Kuning \\ bUniversitas Lancang Kuning \\ abtambusai@yahoo.com
}

\begin{abstract}
This study aims to present information about parents' perceptions of online learning assistance due to the COVID-19 pandemic that has spread throughout the world, including Indonesia. This is very detrimental to all parties, including the world of education. Due to the COVID-19 pandemic, early childhood education must continue to be implemented so that children's rights in education are still accepted by early childhood. Children still have to follow the learning process so that they continue to receive education at home with parental assistance. But of course, online learning is a challenge for parents who do not work and those who work, so that it creates perceptions in every parent of students.
\end{abstract}

Keywords: Mentoring, Learning, COVID-19

\section{PENDAHULUAN}

Pada akhir tahun 2019 munculnya infeksi virus yang menyebar secara cepat, virus tersebut dinamakan COVID-19. Virus ini pertama kali ditemukan di Wuhan, China. COVID19 menyebar secara massif di negaranegara lainnya. World Health Organization (WHO) mengumumkan pada tanggal 11 Maret 2020 bahwa COVID-19 dinyatakan sebagai pandemi. Sampai saat ini ada 215 negara yang terjangkit virus corona, dengan laporan terinfeksi sebanyak 12.768.307 kasus yang terjangkit (WHO, 2020)). Indonesia adalah salah satu negara yang terjangkit COVID-19. Virus ini sudah tersebar di Indonesia pada
Maret lalu hingga hari ini. Sebanyak 72.347kasus positif COVID-19 di Indonesia(Gugus Tugas Percepatan COVID-19 Indonesia, 2020). Pandemi COVID-19 membawa pengaruh kepada semua lintas kehidupan, khusunya pendidikan. Akibat dari pandemic COVID-19, pelaksanaan sekolah dari taman kanak-kanak hingga universitas di tutup. UNESCO mengatakan bahwa 300 juta murid terganggu kegiatan sekolahnya dan penutupan sekolah sementara akibat dari kesehatan dan krisis (Handoyo, 2020)). COVID-19 membuat suatu uji coba terhadap pelaksanaan pendidikan secara daring yang 
dilakukan secara massal (Sun, Tang, \& Zuo, 2020)

Ribuan sekolah di negara lain, termasuk Indonesia, menutup sekolah sebagai upaya untuk menghentikan penyebaran COVID-19 (CNN Indonesia, 2020). Tanggapan UNESCO sebagai lembaga yang bergerak di bidang pendidikan, sangat menyetujui pelaksanaan pembelajaran dengan menggunakan wadah daring upaya pembelajaran jarak jauh, sehingga pembelajaran dapat dijangkau oleh murid dimana pun berada. Perubahan dari pelaksanaan pembelajaran dalam kelas hingga pelaksanaan pembelajaran dalam jaringan ini, yang berperan sebagai aktor terpenting ialah guru dan pendidik, karena mereka adalah pengendali dalam proses pembelajaran (Bao, 2020; Braisilaia \& Kvavadze, 2020). Pengaplikasian pembelajaran daring ini adalah bukti dari revolusi industry 4.0, dimana pengaksesan teknologi tidak terbatas, sehingga memungkinkan pelaksanaan pembelajaran daring atau jarak jauh (Verawardina\& Jama, 2018).

Dengan kondisi tersebut diatas, proses pembelajaran pada jenjang pendidikan anak usia dini haruslah tetap berlangsung, bahkan perhatian kepada mereka diberikan lebih dari kondisi normal. Apalagi pada anak yang orang tuanya menjadi garda terdepan penangan covid19. Anak memerlukan pendidikan untuk mengoptimalkan seluruh aspek perkembangannya (Purwanti, 2013) demi masa depan dalam menempuh jenjang berikutnya
(Kementerian Pendidikan dan Kebudayaan, 2003)

Berdasarkan uraian tersebut, penelitian ini akan mendeskripsikan persepsi orangtua mengenai pendampingan pembelajaran daring selama pandemic COVID-19 di tingkat pendidikan PAUD di TK AL ITTIHAD kota Pekanbaru.

\section{METODE PENELITIAN}

\section{A. Jenis Penelitian}

Penelitian ini merupakan penelitian deskriptif dengan menggunakan pendekatan kuantitatif. Penelitian deskriptif adalah penelitian yang tidak membuat perbandingan variabel itu pada sampel lain dan mencari hubungan variabel itu dengan variabel yang lain (Sugiyono, 2008). Dalam penelitian ini variabel yang akan dideskripsikan permasalahan guru paud pada pembelajaran daring.

\section{B. Waktu dan Tempat Penelitian}

Penelitian ini akan dilakukan secara daring pada bulan September 2020 - Juli 2021.

\section{Populasi dan Sampel Penelitian} Populasi penelitian ini mencakup orangtua anak TK AL ITTIHAD yang berjumlah 8 orang. Karena jumlah sampel kurang dari 100 maka semua guru menjadi sampel penelitian. Adapun teknik pengambilan sampel yaitu total sampling.

\section{Teknik Pengumpulan Data}

Pengumpulan data dalam penelitian ini menggunakan kuisioner dan dokumentasi guna memperkuathasil perolehan data.

1. Kuisioner

Alat yang digunakan untuk mengumpulkan 
data dalam penelitian ini adalah kuisioner. Menurut A. Muri Yusuf (2005:249) kuisioner adalah suatu rangkaian pernyataan yang berhubungan dengan topik tertentu yang diberikan kepada sekelompok individu dengan maksud untuk memperoleh data. Jadi kuisioner adalah seperangkat pernyataan yang harus dijawab oleh responden secara tertulis yang digunakan untuk memperoleh berbagai keterangan langsung dari responden.

\section{Teknik Dokumentasi}

Dokumentasi digunakan sebagai sumber data karena dapat dimanfaatkan untuk proses analisa data. Selain itu, dokumentasi dapat pula menunjuang perolehan data yang ada. Dokumen merupakan catatan peristiwa yang sudah berlalu dalam bentuk tulisan, gambar, atau karya monumental dari seseorang (Sugiyono, 2008: 82).

\section{E. Teknik Pengolahan Data}

Sebagai ahkir dari suatu proses peneltian adalah analisis data, yaitu pengolahan data secara kuantitatif dananalisis secara deskriptif karena penelitian ini bersifat gambaran dan menjelaskan mengenai permasalahan yang ada. Pengolahan data dilakukan setelah semua data terkumpul melalui lembar observasi untuk guru dan untuk anak. Data yang telah terkumpul diolah dengan langkah-langkah sebagai berikut:

1. Memeriksa kelengkapan isian data instrumen yang telah diterima dari validator, guru dan sampel penelitian dalam hal ini anak.

2. Membuat tabel pengolahan data.

3. Menskor dan menghitung jumlah hasil observasi dari responden serta memasukan dalam tabel pengolahandata.

4. Menganalisis data yang telah diperoleh.

Setelah data diolah ditetapkan kriteriapenilaian masing-masing data yang diperoleh yang mengacu pada batasanpengelompokkan kriteria pengolahan data adalah sebagai berikut:

\section{Tabel 3.1 Kriteria Permasalahan Orang Tua}

\begin{tabular}{cc}
\hline Skor & Kriteria \\
$76 \%-100 \%$ & Tidak Ada \\
$51 \%-75 \%$ & Sedikit \\
$26 \%-50 \%$ & Banyak \\
$0 \%-25 \%$ & Sangat Banyak \\
\hline & (Riduwan, 2009)
\end{tabular}

\section{HASIL PENELITIAN}

Berdasarkan hasil dari penelitian maka didapatkan hasil dari pengolahan data didapatkan hasil banyak orangtua yang mendapat masalah selama pembelajaran daring. Beberapa indikator seperti sarana dan prasarana seperti internet, waktu, dan materi/kurikulum. Terdapat $60 \%$ orangtua bermasalah dalam internet, $78 \%$ kendala dalam waktu dan $65 \%$ dalam penguasaan materi atau kurikulum. Hasil tersebut didapatkan dari hasil wawancara secara mendalam pada orangtua anak.

\section{PEMBAHASAN \\ Dari hasil wawancara yang telah dilaksanakan terdapat berbagai kendala yang dihadapi oleh}


orang tua yang berdampak pada penyelenggaraan pembelajaran daring ini. Kendala utama yang dihadapi dalam proses pelaksanaan kegiatan pembelajaran daring ini adalah gangguan signal internet yang cenderung tidak stabil. Selain itu anak bosan karena sudah terlalu lama pembelajaran daring.

' Kendalanya ya itu bun, kadang jaringan internet tidak stabil ntah dari sekolahnya dan kadang kehabisan paket data. Selain itu anak-anak sudah bosan pembelajaran secara ol ni, sering bertanya kapan bisa ke sekolah ketemu teman-teman,apa masih lama belajar daringnya. Ya seperti itu bun,sudah bosan anak ni."

Hal lain yang cukup membebankan orangtua siswa adalah mereka harus mendampingi anak selama pembelajaran daring berlangsung. Hal ini tentu saja menyita waktu para orangtua yang kebanyakan dari mereka yang bekerja. Sulit bagi mereka untuk selalu mendampingi anak-anak di rumah karena mereka yang tidak bekerja juga sibuk mengurus keperluan keluarga. Hal ini tentu menjadi dilema besar bagi para orangtua yang harus bekerja di luar rumah.

' Sangat menguras tenaga dan emosi bu, saya sama sekali tidak bisa mendampingi jadi hanya bisa membantu membuatkan Pr dari gurunya,itu pun kadang terlewatkan karena saya pulang kerja udah capek banget,"

Selain masalah tersebut, factor dari lingkungan tempat tinggal juga cukup berpengaruh banyak dalam proses pembelajaran daring di rumah. Anakanak membutuhkan suasana yang mendukung kegiatan daring ini terlebih mereka hanya didampingi oleh orang tua saja. Seringkali orangtua tidak mengontrol aktivitas anak di rumah menyebabkan anak-anak menjadi ketergantungan pada gadget;

' 'Kadang anak ni kita tinggal sebentar aja yang lain dibukanya. Ntah main gamelah ntah nonton yang lainlah.Jadi, susah juga jadinya kalau tidak didampingi.",

Kurikulum yang dilaksanakan dalam pembelajaran daring juga menjadi kendala bagi orangtua dala melaksanakan pembelajaran daring karena mereka harus memepelajari terlebih dahulu dan baru bisa menerapkannnya.

' 'Kurikulum diberikan dari sekolah bun, jadi ya memang harus dipahami kadang saya mengerti kadang susah juga. Ya memang harus menyesuaikan dengan pembelajaran yang diberikan oleh guru".

Menurut (Oktafia Ika, 2020)keadaan saat ini harus dilihat dari sisi positif yakni kesempatan membangun pola pembelajaran yang lebih baik dan lebih kontekstual. Kesempatan untuk membangun daya kreativitas sebagai guru dan orang tua. Orang tua dan guru tidak boleh menyerah karena saat seperti ini menjadi uji seleksi terhadap kualitas pendidikan. Siapa yang tidak meningkatkan kualitas akan tergerus oleh alam. (Khayankij, 2012)menyatakan bahwa alam menyeleksi secara alamiah terhadap semua makhluk dengan mempertimbangkan aspek teknologi yang terus berkembang dan mempermudah proses kegiatan pemebelajaran di bangku sekolah. Yang perlu diperhatiakan pihak pemerintah adalah menyiapkan infrastruktur yang dapat mendukung program pembelajaran daring dengan meningkatkan akses layanan internet di daerah-daerah pelosok 
pedalaman.(Purwanto, 2019)menyatakan bahwasannya pembelajaran daring masih terdapat kekurangan bila dibandingkan dengan pendidikan konvensional karena interaksi antara guru dan murid merupakan model pembelajaran yang cukup efektif dalam menyampaikan nilainilai yang tidak bisa dicapai apabila menggunakan pembelajaran daring. Pengalaman yang didapat siswa tentu saja tidak bisa diperoleh bila tidak terjadi interaksi antar guru dan murid seperti pada pembelajaran jarak jauh. Covid-19 di Kecamatan Tenayan Raya tentu saja berpengaruh pada hasil belajar anak. Bagi guru PAUD yang terbisa melakukan pembelajaran secara tatap muka, kondisi ini memunculkan ketidaksiapan pembelajaran baik guru maupun anak. Agar sistem pendidikan jarak jauh dapat diselenggarakan dengan baik, maka harus memperhatikan berbagai komponen antara lain bahan, produksi bahan belajar, distribusi bahan belajar, dukungan belajar, penilaian peserta didik, pengolahan administrasi dan mekanisme umpan balik (Perry \& Rumble, dalam Warsita, 2007).

\section{SIMPULAN DAN SARAN}

\subsection{Simpulan}

Berdasarkan hasil penelitian dan pembahasan dapat disimpulkan bahwa terdapat permasalahan orangtua anak TK AL Ittihad dalam mendampingi anak dalam pembelajaran daring . Terdapat kendala yang dialami orang tua dalam pembelajaran daring yaitu keterbatasan penguasaan teknologi, jaringan internet yang tidak stabil, variasi materi bahan ajar dan kurikulum yang harus dipelajari orangtua, serta beberapa tidak dapat mendampingi anak dalam pembelajaran karena pekerjaan.

\subsection{Saran}

Orang tua harus berkomunikasi dengan guru dengan permasalahan yang dihadapi dan mencari solusi agar pemebelajaran daring dapat dilaksanakan dengan baik.

\section{PERNYATAAN TERIMA KASIH}

Terima kasih kepada tim penelitian yang selalu bekerjasama dalam menyelesaikan penelitian ini dan teman mahasiswa yang ikut berperan dalam penelitian ini.

\section{REFERENSI}

Adhe, Kartika. R. (2018). Model Pembelajaran Daring Matakuliah Kajian PAUD di Jurusan PG PAUD Fakultas Ilmu Pendidikan Universitas Negeri Surabaya. Yogjakarta. Jurnal Of Early Childhood Care And Education.

Driyani, Dwi dan Dewi Mustari. (2015). Model Pembelajaran Untuk Taman Kanak-Kanak Berbasis Web.

Jakarta. Vol. 11, No.3.

Gomes, F. (2017). Parental Guidance Service: Kiat Meningkatkan Keterlibatan Orang Tua Dalam Paud. Flores. Jurnal Pendidikan dan Kebudayaan Missio. Vol. 9, No.1.

Haerudin, dkk. (2020). Peran Orang tua Dalam membimbing Anak Selama Pembelajaran Di Rumah Sebagai Upaya Memutus Covid19. Karawang. Universitas Singaperbangsa Karawang.

Novela, Resi dan Yulsyofriend. (2019). Pelaksanaan Kolaborasi Guru Dan Orang Tua Dalam Perkembangan Anak Di Taman Kanak- Kanak Alam Minangkabau Padang. Padang. Selin Jurnal Program Study PGRA.Vol. 5, No 2. 
Nur, dkk. (2016). Peran prang tua dalam memotivasi belajar siswa. Semarang. Indonesian Journal of guuidnce And Counseling. Vol. 5, No. 4.

Pangondian, R, A, Paulus Insap, P. Dkk. (2019). Faktor-Faktor Yang Mempengaruhi Pembelajaran Daring Dalam revolusi Industri. Yogyakarta, Seminar Nasional Teknologi Komputer \& Sains (SAINTEKS). Hal: 56-60

Pujiati, Hanip, dkk. (2018). Membangun Keterlibatan Orang Tua Dalam Pembelajaran Bahasa Inggris Di Paud Melalui Aplikasi Google Classroom Di Kecamatan Cibinong, Kabupaten Bogor. Pakuan. Prosiding Seminar Nasional PGSD. Hal 124-127.

Setyorini, In. (2020) Pandemi Covid-19 Dan Online Learning : Apakah Mempengaruhi Terhadap Proses

Pembelajaran Pada Kurikulum 13?. Journal Of Industrial Engineering \& Management Research

(JIEMAR). Vol :1, N0. 2.

Sukenti,Desi \& Tambak, Syahraini, 2018. Implementasi Budaya Melayu Dalam Kurikulum Pendidikan Madrasah Ibtidaiyah. Pekanbaru : Universitas Islam Riau.
Syafitri, Riska. Desi Purnama, S. dkk. (2020) Implementasi E-Learning Pada Mata Pelajaran Pendidikan Agama Islam Dimasa Pandemi Covid-19. Universitas Sumatera Utara. AL-ULUM Jurnal Pendidikan Islam. Vol. 1, No. 1.

Taliawo, Oni. dkk. (2019). Hubungan Kerjasama Antara Orang Tua Dan Guru Dalam Meningkatkan Minat Belajar Siswa di SMPN ATAP 1 Desa Buo Kecamatan Looda, Halmahera, Maluku Utara. ISSN : 1979-0481. Vol. 12, No. 4. 